\title{
ANALIZA MODELA PROCESA UPRAVLJANJA ZAŠTITOM NA RADU U REPUBLICI HRVATSKOJ
}

UDK 331.45(497.5)

PRIMLJENO: 16.10 .2019 .

PRIHVAĆENO: 10.1.2020.

Ovo djelo je dano na korištenje pod Creative

Commons Attribution 4.0 International License

SAŽETAK: Rad prikazuje analizu modela procesa upravljanja zaštitom na radu u Republici Hrvatskoj. Model procesa proizlazi iz nacionalnih zakonskih odredaba kojima se uređuje ovo područje. U prvom dijelu rada težište se daje na teoretske postavke upravljanja procesima, procesnog pristupa i zaštite na radu. Razumijevanje teoretskih postavki neophodno je zbog provedbe sustavne analize modela procesa upravljanja zaštitom na radu. $U$ drugom dijelu rada prikazuje se analiza modela procesa upravljanja zaštitom na radu. Pri tome se analiziraju ključne dužnosti i obveze sudionika procesa upravljanja zaštitom na radu u Republici Hrvatskoj. Na temelju provedene analize u raspravi i zaključku navode se mogućnosti za poboljšanje upravljanja procesom zaštite na radu u Republici Hrvatskoj.

Ključne riječi: analiza, model, sudionici, upravljanje procesima, zaštita na radu

\section{UVOD}

Organizacije su tradicionalno osmišljene i upravljane u funkcionalnom smislu s organizacijskom shemom. Bilo da je riječ o hijerarhijskom, funkcionalnom i divizijskom ili matričnom susta$\mathrm{vu}$, fokus je na upravljanju definiranim entitetima unutar područja primjene. Međutim, entiteti sami po sebi ne mogu pružiti vanjsku vrijednost. Vrijednost se kolektivno stvara suradnjom između tih funkcionalnih entiteta (Bitkowska, 2015.). Proces je skup uzajamno povezanih ili međusobno ovisnih radnji koje ulazne veličine pretvaraju u rezultate. Danas je upravljanje procesima dobro uspostavljen alat za upravljanje u teoriji i praksi. Upravljanje procesima za cilj ima povećanje učinkovitosti te se stoga smatra osnovom i za gospodarski razvoj i za gospodarstvo u cjelini. Ispitivanje literature otkriva mnoge teoretske koncepte

*Dr. sc. Darko Palačić, (darko.palacic@gmail.com), PHD Consultor d.o.o., 40000 Čakovec, Željka Lalić, (zeljka.lalic@hep.hr), struč. spec. ing. sec., HEP ODS d.o.o., Elektrojug Dubrovnik, Ljubomir Pintarić, (ljubomir.pintaric@colas.hr), spec. geoteh., COLAS HRVATSKA d.d., 42000 Varaždin, Danijel Kurbanjev, (danijel.kurbanjev@gpzagorje), struč. spec. ing. sec., ZAGORJE - TEHNOBETON d.d., 42000 Varaždin. koji se u nekim aspektima mogu znatno razlikovati, čak do točke uzajamne kontradikcije (Meerkamm, 2010.). Što se tiče teorije menadžmenta, jedan od trendova u upravljanju organizacijom je procesni pristup koji sveobuhvatno i horizontalno prati strukturu organizacije. $U$ ovom pristupu, odabrane elemente organizacije koordinira voditelj određenog procesa koji je odgovoran za nadzor i koordinaciju tijeka ovog procesa (Bitkowska, 2016.). Upravo u ovom kontekstu neophodno je provesti analizu modela procesa upravljanja zaštitom na radu koji se temelji na zakonskim odredbama.

\section{Teoretske postavke upravljanja procesima}

Upravljanje poslovnim procesima je polje za upravljanje poslovanjem koje se fokusira na poboljšanje korporativne uspješnosti upravljanjem i optimizacijom poslovnih procesa neke tvrtke. Stoga se može opisati kao proces optimizacije procesa. Upravljanje procesima omogućuje organizaciji da bude učinkovitija i sposobnija za promjene nego ako je funkcionalno usmjerena, 
s tradicionalnim hijerarhijskim pristupom upravljanju. $U$ teoriji postoje 4 procesne metodologije upravljanja procesima: upravljanje ukupnom kvalitetom (TQM), Six Sigma, Lean, ISO 9001 (Chong et al., 2010.). Proces se može definirati kao niz logički povezanih aktivnosti od kojih se zapravo sastoji, uz jasno određene ulaze i izlaze iz procesa (Harrinton, 1991.). Stavi li se to u kontekst poslovanja, poslovni proces sa svojim aktivnostima koristi određene poslovne resurse (ljudske, materijalne, financijske, vremenske, informacijske i dr.) s ciljem zadovoljenja potreba korisnika u najširem smislu. Izlaz iz procesa ostvaruje postavljeni cilj, uz istodobno ostvarivanje nove vrijednosti za organizaciju (Taradi, Grošanić, 2007.). Proces je sam po sebi sustav, odnosno određena logična struktura. Sastavljen je od elemenata, podprocesa, procesnih koraka, aktivnosti, složenih po određenom logičnom slijedu događanja i ima svoju funkciju. Izgradnja procesa na indirektan je način izgradnja cjelokupnog poslovnog sustava ili sustava funkcioniranja nečega, a koji sačinjava niz podsustava poput: podsustav organizacijskog ustroja, dokumentacijski podsustav, informacijski podsustav, komunikacijski podsustav, upravljački podsustavi i procesna struktura i sl. (Drljača, 2003.).

Jedan od osnovnih zadataka osoba koje upravljaju procesima je da su procesu uspješni. Obilježja uspješnih procesa su sljedeća:

- proces treba biti usmjeren na korisnika kome je namijenjen izlaz iz procesa

- izlazi iz procesa trebaju stalno pružati dodanu vrijednost

- proces treba imati sposobnog vlasnika procesa

- proces je razumljiv svima i u odlučivanje su uključeni svi oni koji sudjeluju u procesu

- postavljene su mjere uspješnosti i učinkovitosti procesa

- nužno je neprekidno unapređivanje procesa (Bosilj Vukšić, Kovačić, 2004.).

\section{Teoretske postavke procesnog pristupa}

Postoji mnogo definicija procesnog pristupa, odnosno procesne orijentacije. Pojam procesnog pristupa služi za opis organizacije koja ističe ho- lističke procese pomoću kojih upravlja cijelim lancem vrijednosti nekog proizvoda ili usluge. Također, procesni pristup može se opisati kao sastavnica strukture, fokusa, mjerenja, vlasništva i korisnika (Bosilj Vukšić et al., 2008.).

Procesni pristup podrazumijeva da organizacija upravlja svojim poslovanjem odnosno aktivnostima kao sustavom procesa, a ne odjelima, ljudima ili proizvodima. Primjena procesnog pristupa omogućuje organizaciji da zadovolji zahtjeve korisnika i omogući stalno poboljšavanje. Vizualizacija procesnog pristupa omogućuje interakciju i mapiranje procesa što dodatno može omogućiti bolje organiziranje procesa i često je koristan alat. $\mathrm{U}$ tom smislu često s koriste dijagrami toka koji predstavljaju dobar način da se opišu i raščlane procesi na dijelove kako bi se lakše objasnili i poboljšali procesi. Dijagrami toka omogućuju da se vidi što se točno događa u procesu kao i njihova interakcija.

\section{Teoretske postavke zaštite na radu}

Učinkovito upravljanje zaštitom zdravlja i sigurnošću na radu cilj je svakog poslodavca, pa i države. Sustav upravljanja zaštitom zdravlja i sigurnošću na radu dio je sveukupnog sustava koji ostvaruje upravljanje rizicima za zdravlje koji su svojstveni poslovnim aktivnostima organizacije. Sustav obuhvaća organizacijsku strukturu, planiranje, odgovornost, praksu, postupke, procese, resurse za razvoj, primjenu, ostvarivanje, preispitivanje i održavanje politike zaštite zdravlja i sigurnosti organizacije (Palačić, Mudri, 2014.). Zaštita na radu je interdisciplinarno znanstveno i stručno područje (izlazi iz djelokruga postojećeg ustroja temeljnih znanosti i znanstvenih disciplina) kao i multidisciplinarno područje (jer čini novo polje u kojem postoje mnoge znanstvene discipline koje se tu dodiruju i preklapaju); (Kacian, 1998.). Zaštita na radu može se odrediti i kao sustav tehničkih, zdravstvenih, pravnih, psiholoških, pedagoških i drugih aktivnosti, pomoću kojih se otkrivaju i otklanjaju opasnosti i štetnosti koje mogu ugroziti život i zdravlje osoba na radu ( $P a-$ lačić, 2006.). Zaštita na radu je dio organizacije rada i izvođenja radnog procesa, a ostvaruje se obavljanjem poslova zaštite na radu i primjenom propisanih, ugovorenih, kao i priznatih pravila zaštite na radu te naređenih mjera i uputa poslo- 
davca (Palačić, Živković, 2014.). Za organiziranje i provedbu zaštite na radu odgovoran je poslodavac na temelju objektivne odgovornosti, neovisno o tome je li u tu svrhu zaposlio stručnjaka za zaštitu na radu, odnosno organizirao službu za zaštitu na radu ili je ugovorio suradnju s ovlaštenom fizičkom osobom za zaštitu na radu, ustanovom ili trgovačkim društvom za poslove zaštite na radu. Upravljanje zaštitom zdravlja i sigurnošću na radu nadilazi minimalne zahtjeve koje definiraju propisi iz ovog područja (Palačić, 2011.).

\section{METODOLOGIJA ISTRAŽIVANJA}

\section{Cilj i svrha istraživanja}

Cilj istraživanja je provesti analizu modela procesa upravljanja zaštitom na radu u Republici Hrvatskoj koja podrazumijeva utvrđivanje funkcija, elemente procesa upravljanja i njihovu međusobnu povezanost.

S obzirom da na proces upravljanja zaštitom na radu u Republici Hrvatskoj utječu promjene propisa i objavljivanje novih međunarodnih norma, svrha je istraživanja analizirati i prikupiti saznanja o trenutnoj usklađenosti modela procesa upravljanja s aktualnim odrednicama te predložiti način usklađivanja sa zahtjevima za proces upravljanja koji eventualno nisu uvaženi.

\section{Zadaci istraživanja}

U skladu s postavljenim ciljem, zadaci ovog istraživanja su:

- analizirati i prikazati teoretske postavke upravljanja procesima i zaštitom na radu

- provesti analizu propisa iz područja zaštite na radu i međunarodnih norma

- prikazati utjecaj pojedinih elemenata procesa upravljanja zaštitom na radu

- analizirati model procesa upravljanja zaštitom na radu.

\section{Metode}

Na temelju utvrđenog problema, postavljenog cilja i zadataka znanstvenog istraživanja, izabra- ne su prikladne znanstvene metode koje čine metodiku rada. Metodom studija dokumentacije i sadržaja analiziraju se teoretske postavke upravljanja procesima, postavke procesnog pristupa i zaštite na radu, sadržaj propisa povezanih sa zaštitom na radu te sadržaj međunarodnih norma u vezi sa zaštitom na radu.

Teoretske postavke upravljanja procesima, procesnog pristupa i zaštite na radu analiziraju se iz odabrane znanstvene literature. Sadržaj propisa i norma analiziraju se u svim propisima koji reguliraju ovo područje.

Metodom analize raščlanjuje se model procesa upravljanja zaštitom na radu, nakon čega se metodom deskripcije opisuje i prikazuje analiza modela. Nakon provedene analize i usporedbe sintetiziraju se bitna svojstva i izvode zaključci.

\section{REZULTATI I RASPRAVA}

\section{Prikaz modela procesa upravljanja zaštitom na radu}

$\mathrm{Na}$ temelju navedenih teoretskih postavki upravljanja procesima, procesnog pristupa i zaštite na radu postavljen je model procesa upravIjanja zaštitom na radu u Republici Hrvatskoj ( $L a-$ lić et al., 2019.).

Najčešći problem borbe sa složenošću sustava jest problem modeliranja. Stoga su grafičke metode odlično sredstvo jednoznačnog sporazumijevanja. S obzirom na mnoge grafičke metode koje se mogu koristiti za modeliranje, odluka o odabiru metode treba ovisiti o tome jesu li i u kojoj mjeri zadovoljeni pojedini kriteriji prikazivanja.

Procesi zaštite na radu definirani su nacionalnim propisima i međunarodnim normama iz ovog područja. Proces zaštite na radu dio je organizacije rada i izvođenja radnog procesa, a ostvaruje se obavljanjem poslova zaštite na radu i primjenom propisanih, ugovorenih, kao i priznatih pravila zaštite na radu te naređenih mjera i uputa poslodavca. $U$ tom smislu, ovisno o broju zaposlenih, moguće je na nekoliko načina organizirati obavljanje poslova zaštite na radu. 


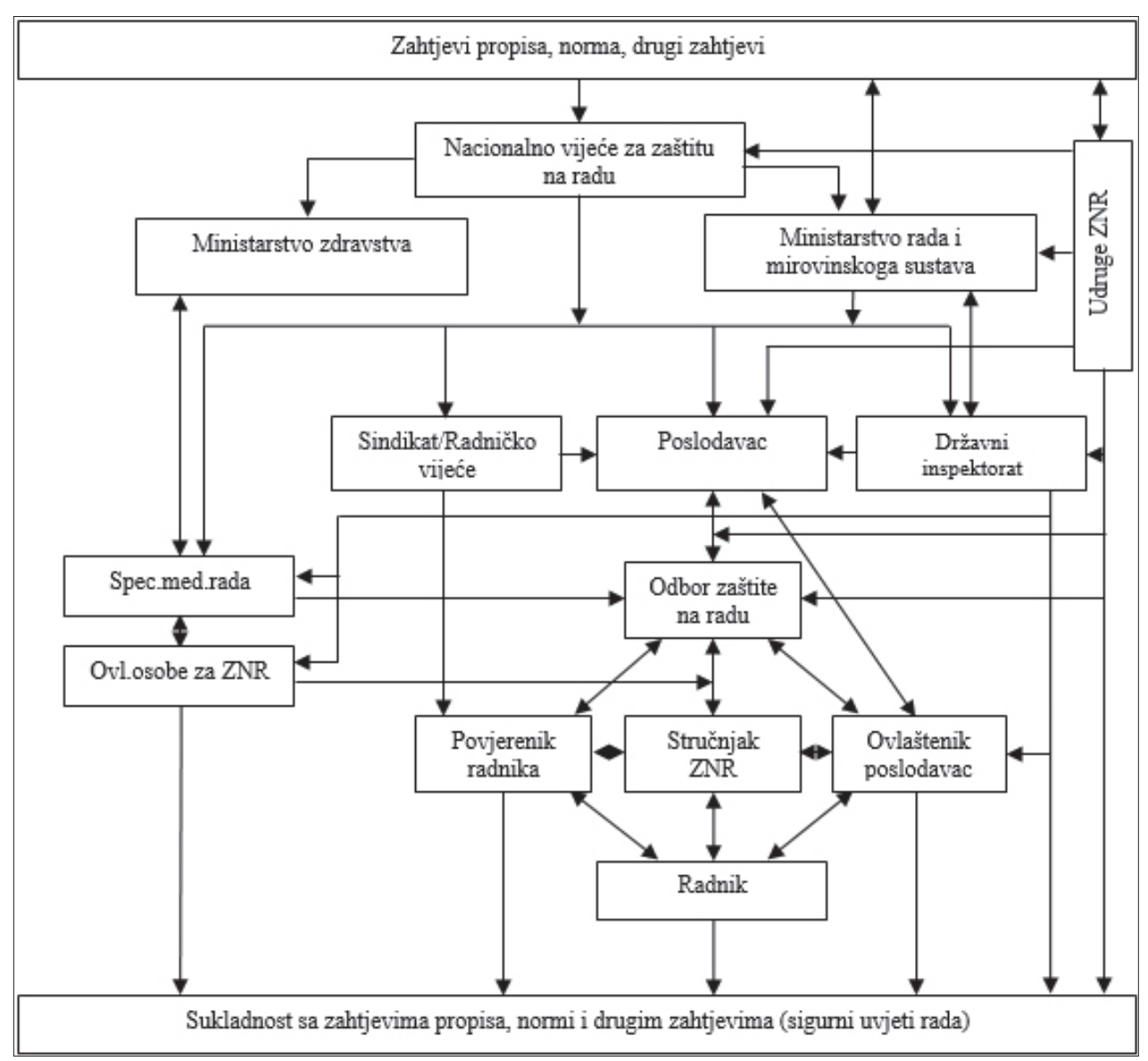

Slika 1. Model tijeka procesa upravljanja zaštitom na radu u Republici Hrvatskoj

Figure 1. Occupational safety process management model in Croatia

Na nacionalnoj razini procesi zaštite na radu na osnovi propisa određuju od kojih se elemenata sastoje. Na nacionalnoj razini ciljeve se postavljaju od strane Vlade $\mathrm{RH}$, na temelju donesenih strategija. Nacionalno vijeće za zaštitu na radu prati postignuće ciljeva. Na razini poslodavca, svaki od poslodavaca postavlja vlastite ciljeve zaštite na radu i brine za njihovo postizanje. U slučaju da mjere koje se poduzimaju za ostvarivanje ciljeva ne daju tražene rezultate, na svakoj se razini trebaju poduzimati korektivne radnje. Za nadzor provedbe procesa zaštite na radu i njegovu usklađenost sa zakonskim zahtjevima nadležan je Inspektorat rada.

\section{Analiza modela procesa zaštite na radu}

Prema prikazanom modelu nadalje se prikazuje analiza modela detaljnijim pojašnjavanjem funkcija i utjecaja sudionika procesa upravljanja zaštitom na radu. Pri tome se uvažavaju zakonski zahtjevi koji definiraju međuodnose svih sastavnica modela upravljanja.

\section{Nacionalno vijeće za zaštitu na radu}

Osnivanje Nacionalnog vijeća za zaštitu na radu predviđeno je na temelju članka 6., stavka 3. Zakona o zaštiti na radu zbog savjetovanja Vlade $\mathrm{RH}$ u utvrđivanju, predlaganju, provođenju i preispitivanju politike zaštite na radu te poticanju na usklađivanje zakonodavstva. Nacionalno vijeće za zaštitu na radu prvi put je osnovano 5.10.2000. godine Odlukom Vlade RH o osnivanju Nacionalnog vijeća za zaštitu na radu. Nacionalno vijeće za zaštitu na radu u današnjem sazivu osnovano je na sjednici Vlade RH od 15.3.2019. godine, Odlukom Vlade RH o osnivanju Nacionalnog vijeća za zaštitu na radu (N.N., br. 27/19.). Zadaci Nacionalnog vijeća su: 
- redovito prati i analizira provedbu politike zaštite zdravlja i sigurnosti na radu i o svojim nalazima i ocjenama izvješćuje Vladu Republike Hrvatske;

- proučava zakone i druge propise kojima se štiti sigurnost i zdravlje osoba na radu te, prema potrebi, predlaže Vladi Republike Hrvatske njihovo usklađivanje međusobno i s međunarodnim propisima;

- daje mišljenje na nacrte propisa iz područja sigurnosti i zaštite zdravlja na radu;

- prati, izučava i ocjenjuje sustav i politiku sigurnosti i zaštite zdravlja na radu;

- predlaže mjere za unapređenje sustava sigurnosti i zaštite zdravlja na radu;

- prati primjenu propisa iz područja sigurnosti i zaštite zdravlja na radu;

- razmatra izvješća Ministarstva gospodarstva, rada i poduzetništva, Ministarstva zdravstva i socijalne skrbi, Državnog inspektorata i Hrvatskog zavoda za javno zdravstvo u vezi s pitanjem sigurnosti i zaštite zdravlja na radu;

- organizira obilježavanje Dana zaštite na radu;

- obavlja i druge poslove na zahtjev Vlade Republike Hrvatske.

\section{Ministarstvo rada i mirovinskoga sustava}

Ministarstvo rada i mirovinskoga sustava (MRMS) je središnje tijelo državne uprave u Republici Hrvatskoj koje obavlja upravne i druge poslove koji se odnose na: politiku zapošljavanja, uređivanje radnih odnosa, tržište rada i aktivnu politiku zapošljavanja, programe radnih prekvalifikacija i povećanja zapošljivosti itd. Između ostaloga, Ministarstvo obavlja poslove koji se odnose na unapređenje sustava zaštite na radu. MRMS sudjeluje u pripremi programa i projekata te provedbi projekata iz programa Europske unije i ostalih oblika međunarodne pomoći. Unutar Ministarstva ustrojen je Sektor za zaštitu na radu koja obavlja cijeli spektar različitih stručnih poslova u vezi s izradom prijedloga propisa, koordinacijom, obavještavanjem i sl.

\section{Ministarstvo zdravstva}

Ministarstvo zdravstva je središnje tijelo državne uprave u RH koje obavlja upravne i druge poslove koji se odnose na: sustav zdravstvene zaštite i zdravstvenog osiguranja, praćenje i unapređivanje zdravstvenog stanja i zdravstvenih potreba stanovništva. Opći cilj Ministarstva je zaštita, unapređenje i očuvanje zdravlja.

\section{Državni inspektorat}

Državni inspektorat obavlja inspekcijske i druge stručne poslove u području rada i zaštite na radu, obavljajući inspekcijske nadzore provedbe zakona i drugih propisa kojima se uređuju, kao što su radni odnosi i zaštita na radu te druge sastavnice u vezi s radnim odnosima i uvjetima rada. Inspektori rada Ministarstva rada i mirovinskoga sustava provode inspekcijski nadzor nad provedbom Zakona o zaštiti na radu i pripadajućih podzakonskih propisa. Poslodavac je dužan inspektoru pružati svu dokumentaciju koju isti zatraži te postupati prema uputama istih. Za navedeno je poslodavac dužan postupiti prema nalogu inspektora radu i u slučaju da je po nalogu inspektora rada izdano rješenje, postupiti po tom rješenju. Inspektor rada može i zatražiti od poslodavca da privremeno prekine s radom ako nije moguće drugačije obaviti inspekcijski nadzor. Inspektoru radu dopušteno je fotografirati prostore i prostorije poslodavca kao i osobe na radu. Inspektor može usmenim rješenjem zabraniti poslodavcu uporabu neispravnih sredstava rada i osobnih zaštitnih sredstava, narediti izradu procjene rizika, osnivanje odbora ZNR, ispitivanje radne okoline, postavljanje znakova sigurnosti i radnih uputa te ispitivanje radne opreme, kao i udaljiti s mjesta radnika za kojeg nije predočio dokaze o ispunjavanju uvjeta za navedeno radno mjesto, pri čemu će sve spomenuto upisati u zapisnik o provedbi inspekcijskog nadzora. Rješenjem o izvršavanju obveza može se odrediti i dodatni rok te nakon što je isto postalo izvršeno, inspektor rada će izvršiti kontrolu istoga.

\section{Poslodavac}

Poslodavac je fizička ili pravna osoba za koju radnik odnosno osoba na radu obavlja poslove. Njegova obveza je organizirati provedbu zaštite na radu, brinuti o provođenju zakonskih propisa te po potrebi i ovisno o broju zaposlenika i procijenjenim opasnostima, zaposliti jednog ili više stručnjaka zaštite na radu. Jedan od načina suradnje stručnjaka zaštite na radu i upoznavanje poslodavca s problemima u provođenju mjera za- 
štite na radu je prisustvovanje poslodavca na sjednicama odbora zaštite na radu. Najvažnije obveze poslodavca o pitanju zaštite na radu propisane su Zakonom o zaštiti na radu. Utjecaj poslodavca na provedbu mjera zaštite na radu treba biti proaktivan i u bezrezervnoj podršci stručnjacima zaštite na radu. Poslodavac je dužan savjetovati se s povjerenikom radnika u slučaju da u tvrtki postoji povjerenik radnika. U suradnji s radnicima, stručnjacima zaštite na radu, povjerenicima radnika te striktnim poštovanjem zakonskih odredbi, provođenje zaštite na radu može se dovesti na zavidnu razinu što svakako utječe i na ugled i promociju poslodavca kao poželjnog poslodavca.

\section{Ovlaštenici poslodavca}

Ovlaštenik je radnik kojem je poslodavac, neovisno o drugim ugovorenim poslovima, dao ovlaštenja za provedbu zaštite na radu. Pravno gledajući nije svaki voditelj ovlaštenik nego je ovlaštenik radnik koji je osposobljen za poslove ovlaštenika. Poštovanje zakonskih propisa i provođenje istih te otklanjanje rizika može utjecati na smanjenje ozljeda na radu i isto tako na smanjenje troškova poslodavca u broju izgubljenih dana rada radnika. Osposobljavanje ovlaštenika provode stručnjaci zaštite na radu zaposleni kod poslodavca ili sam poslodavac, odnosno poslodavac svojom internom odlukom propisuje obveze ovlaštenika poslodavca te mu isto predaje u pisanom obliku, a samom odlukom ne prestaje odgovornost poslodavca u provođenju mjera zaštite na radu. Poslodavac koji zaštitu na radu provodi djelovanjem ovlaštenika obvezan je ovlastiti ovlaštenika za sve mjere propisane Zakonom o zaštiti na radu. Dakle, ovlaštenik poslodavca u ime poslodavca i za poslodavca preuzima rizik odgovornosti te nadzire provođenje mjera zaštite na radu. Ovlaštenik poslodavca ne može obavljati poslove stručnjaka zaštite na radu. Također, ovlaštenik surađuje s inspekcijom zaštite na radu prilikom inspekcijskog nadzora. Osposobljavanje ovlaštenika provodi stručnjak zaštite na radu zaposlen kod poslodavca ili sam poslodavac. Osposobljavanje ovlaštenika provodi se svakih pet godina, a u tom razdoblju ovlaštenik poslodavca dužan je usavršavati se te prisustvovati seminarima i radionicama.

\section{Povjerenici radnika za zaštitu na radu}

Povjerenik radnika za zaštitu na radu je radnik koji je u skladu sa Zakonom o zaštiti na radu izabran od strane ostalih radnika da zastupa njihove interese na području zaštite na radu te da prati primjenu pravila, mjera, postupaka i aktivnosti zaštite na radu. Ako je prema propisanim kriterijima kod poslodavca izabrano više povjerenika, oni između sebe biraju svojeg koordinatora. Poslodavac je obvezan, unaprijed i pravodobno, savjetovati se s povjerenikom radnika za zaštitu na radu o svim činjenicama koje Zakon o zaštiti na radu utvrđuje svojim odredbama u članku 33., dok je povjerenik radnika obvezan štititi interese radnika. Poslodavac je obvezan povjereniku radnika za zaštitu na radu osigurati potrebno vrijeme za nesmetano obnašanje dužnosti, davati sve potrebne obavijesti i omogućiti mu uvid u sve propise $\mathrm{i}$ isprave iz zaštite na radu te mu osigurati uvjete za nesmetano obnašanje dužnosti u skladu s općim propisima o radu kojima su propisani uvjeti za rad radničkog vijeća (Lalić et al., 2017.).

\section{Odbor zaštite na radu}

Poslodavac koji zapošljava 50 ili više radnika obvezan je osnovati odbor zaštite na radu kao svoje savjetodavno tijelo za unapređivanje zaštite na radu. Iznimno, odbor je obvezan osnovati i poslodavac koji zapošljava manje od 50 radnika ako je to propisano posebnim zakonom ili drugim propisom. Odbor čine poslodavac ili njegov ovlaštenik, stručnjak zaštite na radu koji obavlja poslove zaštite na radu kod poslodavca, specijalist medicine rada izabran u skladu s posebnim propisom te povjerenik radnika za zaštitu na radu ili njihov koordinator. Odbor se sastaje najmanje jedanput u šest mjeseci i o svojem radu vodi zapisnik. Iznimno, u slučaju smrtne ozljede nastale u prostoriji ili na prostoru u kojem poslodavac obavlja rad, ozljede nastale u prostoriji ili na prostoru u kojem poslodavac obavlja rad zbog koje je radniku ili osobi na radu pružena hitna medicinska pomoć i zbog koje je ozlijeđena osoba zadržana na liječenju u stacionarnoj zdravstvenoj ustanovi ili dnevnoj bolnici, utvrđenog slučaja profesionalne bolesti ili nalaza nadležnog inspektora kojim je utvrđen nedostatak u provedbi zaštite na radu, 
poslodavac je obvezan sazvati sjednicu u roku od dva radna dana od nastanka ozljede.

\section{Sindikati i radnička vijeća}

Radnici imaju pravo, po svojem slobodnom izboru, utemeljiti sindikat te se u njega učlaniti, uz uvjete koji mogu biti propisani samo statutom ili pravilima toga sindikata. Sindikat je organizacija koju stvaraju radnici. Radnici zaposleni kod poslodavca koji zapošljava najmanje dvadeset radnika, osim radnika zaposlenih u tijelima državne uprave, imaju pravo sudjelovati u odlučivanju o pitanjima u vezi s njihovim gospodarskim i socijalnim pravima i interesima na način i pod uvjetima propisanim Zakonom o radu. Radnici imaju pravo na slobodnim i neposrednim izborima, tajnim glasanjem, izabrati jednog ili više svojih predstavnika (radničko vijeće) koji će ih zastupati kod poslodavca u zaštiti i promicanju njihovih prava i interesa. Radničko vijeće štiti i promiče interese radnika zaposlenih kod određenog poslodavca, savjetovanjem, suodlučivanjem ili pregovorima s poslodavcem ili od njega opunomoćenom osobom, o pitanjima važnima za položaj radnika. Radničko vijeće pazi na poštovanje Zakona, pravilnika o radu, kolektivnih ugovora te drugih propisa, pazi ispunjava li poslodavac uredno i točno obveze obračunavanja i uplaćivanja doprinosa u skladu s posebnim propisom te $u$ tu svrhu ima pravo uvida u odgovarajuću dokumentaciju.

\section{Radnici}

Radnik u smislu Zakona o radu i Zakona o zaštiti na radu je fizička osoba koja u radnom odnosu obavlja određene poslove za poslodavca. Poslove kod poslodavca mogu obavljati i osobe na radu, strani radnici te posebno osjetljive skupine radnika. Radnik je za poslodavca obvezan i odgovoran obavljati poslove dužnom pažnjom i pri tome je dužan voditi računa o svojoj sigurnosti i zaštiti zdravlja kao i o sigurnosti i zaštiti zdravlja ostalih radnika koje bi mogli ugroziti njegovi postupci ili propusti u radu. Kako bi radnik mogao provoditi poslove dužnom pažnjom, obvezan je osposobljavati se za rad na siguran način te raditi prema uputama poslodavca i njegovih ovlaštenika. Također je obvezan surađivati s poslodavcem, njegovim ovlaštenikom, stručnjakom zaštite na radu, povjerenikom i specijalistom medicine rada u rješavanju svih pitanja zaštite na radu u skladu sa Zakonom i ostalim podzakonskim propisima.

\section{Specijalist medicine rada}

Kako bi poslodavac mogao provoditi zdravstveni nadzor svojih radnika primjeren rizicima za sigurnost i zdravlje kojima su radnici izloženi na radu, opasnostima, štetnostima i naporima tijekom rada, obvezan im je osigurati usluge medicine rada. Poslodavac ugovora usluge medicine rada sa zdravstvenom ustanovom koja obavlja djelatnost medicine rada, odnosno sa specijalistom medicine rada u privatnoj praksi, u skladu s propisima o zdravstvenoj zaštiti i zdravstvenom osiguranju. Poslovi medicine rada, uključujući plan i program mjera zdravstvene zaštite, propisani su posebnim propisima o zdravstvenoj zaštiti i zdravstvenom osiguranju (Učur, 2016.).

Specijalist medicine rada je član odbora za zaštitu na radu, obavlja pregled radnika po uputi poslodavca i utvrđuje je li radnik sposoban za obavljanje poslova s posebnim uvjetima rada u skladu s procjenom rizika te ocjenjuje kada radnik ponovno mora doći na periodički, kontrolni ili izvanredni specijalistički pregled. Specijalist medicine rada daje ocjenu o rizicima koji bi mogli štetno utjecati na sigurnost i zdravlje trudnih radnica, na njihov plod, radnica koje su nedavno rodile i radnica koje doje, na temelju procjene rizika, daje ocjenu zdravstvene i psihofizičke sposobnosti radnika koji se nalazi u programu liječenja odvikavanja ili rehabilitacije od ovisnosti. Specijalisti medicine rada profesionalno su neovisni u odnosu na poslodavca, njegove ovlaštenike, radnike, povjerenike i stručnjake zaštite na radu, ali su obvezni surađivati s njima i s nadležnim inspektorima.

\section{Stručnjak zaštite na radu}

Pojam stručnjaka zaštite na radu kao radnika kojeg je poslodavac odredio za obavljanje poslova zaštite na radu i koji ispunjava propisane uvjete za obavljanje tih poslova definiran je Zakonom o zaštiti na radu i pravilnicima koji iz njega proizlaze. Stručnjak zaštite na radu može kod poslodavca obavljati poslove zaštite na radu kao stručnjak zaštite na radu I. ili II. stupnja (Lise, Lalić, 2016.). Poslovi zaštite na radu koje za poslodavca obavlja stručnjak zaštite na radu su: 
- stručna pomoć poslodavcu i njegovim ovlaštenicima, radnicima te povjerenicima radnika za zaštitu na radu u provedbi i unapređivanju zaštite na radu

- sudjelovanje u izradi poslovne strategije te operativnih planova i programa poslovanja poslodavca, u dijelu u kojem se moraju odnositi na zaštitu na radu, te sudjelovanje u primjeni upravljačkih metoda ili tehnika za provođenje strategije

- sudjelovanje u postupku izrade procjene rizika

- unutarnji nadzor nad primjenom pravila zaštite na radu te poticanje i savjetovanje poslodavca i njegovih ovlaštenika da otklanjaju nedostatke u zaštiti na radu utvrđene unutarnjim nadzorom

- prikupljanje i analiziranje podataka u vezi s nezgodama, ozljedama na radu, profesionalnim bolestima i bolestima u vezi s radom te priprema propisanih prijava ozljeda na radu i profesionalnih bolesti i izrada izvješća za potrebe poslodavca

- suradnja s tijelima nadležnima za poslove inspekcije rada, sa zavodom nadležnim za zaštitu zdravlja i sigurnost na radu, ovlaštenim osobama te sa specijalistom medicine rada

- osposobljavanje radnika, poslodavca i ovlaštenika za rad na siguran način

- osposobljavanje povjerenika radnika za zaštitu na radu i pomaganje u njihovom djelovanju

- djelovanje u odboru za zaštitu na radu kod poslodavca

- suradnja s poslodavcem prilikom projektiranja, građenja i rekonstrukcije građevina namijenjenih za rad, nabave radne opreme i ostalih sredstava rada, osobne zaštitne opreme i opasnih kemikalija

- sudjelovanje u primjeni međunarodnih certifikacijskih normi za upravljanje zaštitom na radu, kvalitetom, rizicima, društvenom odgovornošću u poslovanju i sl. kod poslodavca

- ostali poslovi zaštite na radu u skladu s potrebama poslodavca.
Poslodavac je obvezan stručnjaku zaštite na radu omogućiti stalno stručno usavršavanje, ispunjavanje obveza, osigurati mu potrebno vrijeme, opremu, pomoć drugih stručnih radnika i ostale uvjete za rad, kao i profesionalnu neovisnost te ga ne smije staviti u nepovoljniji položaj zbog obavljanja poslova zaštite na radu prema Zakonu o zaštiti na radu, drugih propisa i pravila struke (Taradi et al., 2015.).

\section{Udruge zaštite na radu}

Utjecaj udruga, odnosno nevladinih organizacija svakim je danom sve veći. Udruge u području zaštite na radu osnivaju se u cilju promicanja, razvitka i unapređenja zaštite zdravlja i sigurnosti na radu, a posebno zbog okupljanja stručnjaka koji se bave poslovima zaštite na radu, ostvarivanja sigurnijih uvjeta rada, poticanja međusobne suradnje na području djelovanja, unapređivanja sigurnosti u teoriji i praksi, zaštite pojedinačnih i skupnih interesa, te stalne informiranosti članstva.

\section{Ovlaštene osobe za zaštitu na radu}

Obavljanje poslova zaštite na radu uređeno je nizom propisa. Pravilnikom o ovlaštenjima za poslove zaštite na radu propisuju se uvjeti pod kojima poslodavac za svoje potrebe i fizička ili pravna osoba mogu biti ovlašteni za obavljanje poslova zaštite na radu, postupak izdavanja, oduzimanja i prestanak ovlaštenja, stručni nadzor nad obavljanjem poslova za koje su ovlašteni te obveze i način evidentiranja izdanih i oduzetih ovlaštenja i rješenja o prestanku ovlaštenja. Poslovi zaštite na radu za koje se izdaje ovlaštenje su:

- obavljanje poslova zaštite na radu kod poslodavca

- osposobljavanje za zaštitu na radu (osposobljavanje radnika za rad na siguran način te osposobljavanje poslodavca, ovlaštenika i povjerenika radnika za zaštitu na radu)

- izrada procjene rizika

- ispitivanje radne opreme

- ispitivanja fizikalnih, kemijskih i bioloških čimbenika u radnom okolišu.

Za odbijanje pojedinih ovlaštenja tvrtke moraju ispunjavati propisane kadrovske uvjete u skladu s navedenim pravilnikom. Ovlaštena osoba 
mora za sve poslove zaštite na radu koje obavlja izraditi poslovnik o postupcima, uvjetima i metodama obavljanja tih poslova. Poslovnici te postupci, uvjeti i metode u poslovnicima, moraju biti izrađeni u skladu s normom HRN ISO/TR 10013. Ispitivanja se moraju obavljati u skladu s propisima u mjeriteljstvu.

Ovlaštene osobe obvezne su izdavati isprave o provedenim ispitivanjima radne opreme, odnosno radnog okoliša te vode evidencije, čuvaju isprave, daju obavijesti te podatke u skladu sa Zakonom o zaštiti na radu i drugim propisima zaštite na radu, putem informacijskog sustava zaštite na radu.

\section{ZAKLJUČAK}

Nakon provedene analize i rasprave može se konstatirati da su ciljevi i zadaci ovog istraživanja postignuti. Provedenim istraživanjem analizirane su i prikazane teoretske postavke upravljanja procesima, procesnog pristupa i zaštite na radu te su analizirani propisi iz područja zaštite na radu i međunarodnih norma.

Analizom modela procesa upravljanja zaštitom na radu u Republici Hrvatskoj i raspravom obuhvaćeni su osnovni elementi tog procesa upravljanja. Ključni sudionici procesa upravljanja zaštitom na radu su Nacionalno vijeće za zaštitu na radu, Ministarstvo rada i mirovinskoga sustava, Ministarstvo zdravstva, Državni inspektorat, poslodavac, ovlaštenici poslodavca, povjerenici radnika za zaštitu na radu, odbor zaštite na radu, sindikati i radnička vijeća, radnici, specijalist medicine rada, stručnjak zaštite na rada, udruge zaštite na radu te ovlaštene osobe za zaštitu na radu. Svaki od elemenata ovog procesa upravljanja ima svoju ulogu u cjelokupnom procesu. Provedenom analizom modela utvrđeno je da je proces upravljanja zaštitom na radu u Republici Hrvatskoj iznimno složen. To se jasno vidi u prikazanom modelu i analizi zadataka pojedinih ključnih sudionika procesa. Međuodnosi između ključnih sudionika procesa upravljanja su definirani, no pojednostavljenje tog odnosa pridonijelo bi uspostavljanju učinkovitijeg sustava upravljanja procesima zaštite na radu. Dakle, temeljni zaključak analize je da je neophodno pojednostavljenje procesa upravljanja zaštitom na radu.
S obzirom da je državi i svim sudionicima ovog procesa $u$ interesu da proces upravljanja bude učinkovitiji, za očekivati je da je moguće provesti redefiniranje i restrukturiranje (promjena strukture) procesa upravljanja zaštitom na radu. Takvo se pojednostavljenje procesa upravljanja može postići promjenama zakonske regulative kojima se stvaraju preduvjeti za redefiniranje $\mathrm{i}$ restrukturiranje proces, te osnivanjem strukovne komore (komora zaštite zdravlja i sigurnosti na radu) koja bi preuzela dio javnih ovlasti koje se sada nalaze u ingerenciji nekoliko ministarstava.

Komorskim organiziranjem područja zaštite na radu jasno bi se razgraničile ovlasti za donošenje propisa, izdavanje dopuštenja za rad pravnim i fizičkim osobama, te nadzor provedbe. Primjenom ovog pristupa Ministarstvo rada i mirovinskog sustava u suradnji s drugim ministarstvima zadržalo bi ingerenciju za donošenje propisa kojima se uređuje područje zaštite na radu. Novoosnovana komora preuzela bi javne ovlasti vezano za izdavanje dopuštenja pravnim i fizičkim osobama za obavljanje poslova zaštite na radu, te polaganje stručnih ispita iz područja zaštite na radu. Ostale javne ovlasti komore (ispiti, permanentna edukacija svih stručnjaka zaštite na radu, organiziranje edukacije, uvjeti za izdavanje dopuštenja i sl.) propisale bi se aktima koji reguliraju ovlasti i rad komore. Nadzor nad provedbom zaštite na radu i radom ovlaštenih pravnih i fizičkih osoba isključiva je ovlast Državnog inspektorata.

Kako bi se utvrdio stvaran utjecaj pojedinih ključnih sudionika procesa upravljanja zaštitom na radu, predlaže se pokretanje nastavka istraživanja s tim ciljem. Rezultati tog istraživanja mogli bi se iskoristiti za daljnje definiranje procesa upravljanja zaštitom na radu u Republici Hrvatskoj.

\section{LITERATURA}

Bitkowska, A.: Knowledge management vs business process management in contemporary enterprises, Economics and Management, 8, 2016. 2, 31-37.

Bitkowska, A.: The Orientation of Business Process Management toward the Creation of 
Knowledge in Enterprises, Human Factors and Ergonomics in Manufacturing \& Service Industries, 25, 2015., 1, 43-57.

Bosilj Vukšić, V., Kovačić, A.: Upravljanje poslovnim procesima, Sinergija, Zagreb, 2004.

Bosilj Vukšić, V., Hernaus, T., Kovačić, A.: Upravljanje poslovnim procesima - organizacijski i informacijski pristup, Školska knjiga, Zagreb, 2008.

Chong, A.Y.L., Ooi, K.B., Lin, B., Teh, P.L.: TQM, knowledge management and collaborative commerce adoption: A literature review and research framework, Total Quality Management \& Business Excellence, 21, 2010., 5, 457-473.

Drljača, M.: Principi izgradnje poslovnih procesa, Elektrika, 5, 2003., 23, 24-29.

Eur Lex Europa, dostupno na: https://eurlex.europa.eu/eu-enlargement/hr/special. html? locale=hr. pristupljeno: 11.3.2019.

European Agency for Safety and Health at Work, dostupno na: https://osha.europa.eu/ en/safety-and-health-legislation. pristupljeno: 11.3.2019.

Harrinton, H. J.: Business Process Improvement, McGraw-Hill, New York, 1991.

HRN EN ISO 9000:2015, Sustav upravljanja kvalitetom - Temeljna načela i rječnik

HRN EN ISO 9001:2015, Sustav upravljanja kvalitetom - Zahtjevi

Hrvatski zavod za javno zdravstvo, dostupno na: http://hzzzsr.hr/index.php/medicina-rada/, pristupljeno: 20.2.2019.

Hrvatski zavod za zdravstveno osiguranje, dostupno na: https://www.hzzo.hr/zastita-zdravljana-radu/. pristupljeno: 15.3.2019.

International Organization for Standardization, dostupno na: http://www.iso.org, pristupljeno: 1.3.2019.

ISO 45001:2018, Sustavi upravljanja zdravljem i sigurnošću na radu - Zahtjevi

Kacian, N.: Osnove sigurnosti, Zagreb, IPROZ, 1998.
Lalić, Ž., Hrgarek, M., Ružić, I., Kurbanjev, D., Pintarić, Lj.: Uloga stručnjaka zaštite na radu i povjerenika radnika u poslovnom sustavu sukladno novom zakonu o zaštiti na radu, U: 4. Međunarodna stručno znanstvena konferencija "Odbor za zaštitu na radu", Čakovec 2017.

Lalić, Ž., Palačić, D., Pintarić, Lj., Kurbanjev, D.: Model procesa upravljanja zaštitom na radu u Republici Hrvatskoj, U: 14th International Conference Management and Safety 2019, ESSE, Budva, 14, 2019., 169-181.

Lise, I., Lalić, Ž.: Položaj stručnjaka zaštite na radu u poslovnom sustavu sukladno novom zakonu o zaštiti na radu, U: 6. Međunarodni stručnoznanstveni skup "Zaštita na radu i zaštita zdravlje", Zadar, Hrvatska, 2016.

Meerkamm S.: The Concept of Process Management in Theory and Practice - A Qualitative Analysis. In: Rinderle-Ma S., Sadiq S., Leymann F. (eds) Business Process Management Workshops. BPM 2009. Lecture Notes in Business Information Processing, 43. Springer, Berlin, Heidelberg, 2010.

Ministarstvo rada i mirovinskoga sustava, dostupno na: https://www.mrms.hr/. pristupljeno: 17.3.2019.

Narodne Novine, dostupno na: https://narodnenovine.nn.hr/search.aspx, pristupljeno: 2.4.2019.

Palačić, D.: Menadžment sigurnosti, Zaštita, 2, 2006., 1, 23-25.

Palačić, D.: Sustavi upravljanja sigurnošću, IPROZ, Zagreb, 2011.

Palačić, D., Mudri, M.: Defining Policy for Management of Occupational Health, Safety at work and Environmental Protection in order to Manage the Crisis in a Business Organization, Collegium Antroplologicum, 38, 2014., Suppl. 1, 13-24.

Palačić, D., Živković, S.: Primjena norme OHSAS 18001 i ISO 14001 u funkciji poboljšanja komuniciranja u području zaštite zdravlja, sigurnosti na radu i zaštite okoliša pri upravljanju kriznim situacijama u poslovnoj organizaciji, U: 7. Međunarodna znanstveno - stručna konferencija 'Dani kriznog upravljanja', Veleučilište Velika Gorica, Velika Gorica, 747-766, 2014. 
Pravilnik o osposobljavanju iz zaštite na radu $i$ polaganju stručnog ispita, N.N., br. 112/14.

Pravilnik o izradi procjene rizika, N.N., br. 112/14.

Pravilnik o obavljanju poslova zaštite na radu, N.N., br. 112/14., 43/15., 72/15., 140/15.

Pravilnik o ovlaštenjima za poslove zaštite na radu, N.N., br. 112/14., 84/15.

Pravilnik o načinu i postupku izbora doktora specijalista medicine rada, N.N., br. 12/14., 53/17.

Središnji katalog službenih dokumenata $R H$, dostupno na: http://www.digured.hr/. pristupljeno: 2.3.2019.

Taradi, J., Grošanić, N.: Procesni pristup i model upravljanja zakonskim zahtjevima sigurnosti u poslovnom sustavu, U: Zbornik Radova II. Znanstveno-stručne konferencije s međunarodnim sudjelovanjem "Menadžment i sigurnost",
Hrvatsko društvo inženjera sigurnosti, Čakovec, 60-76, 2007.

Taradi, J., Nikolić, V., Anđelković, B., Šijaković, A., Grošanić, N.: Stres na poslovima stručnjaka za zaštitu na radu, U: 10. International Conference "Management and safety" M\&S 2016, Conference theme: Stress Management and Safety, Europsko društvo inženjera sigurnosti, Opatija, 90-105, 2015.

Učur, Đ. M.: Posebni subjekti i odnosi u zaštiti na radu, U: 11. International Conference "Management and safety" M\&S 2016, Conference theme: Sustainable development and safety, ESSE, Vrnjačka Banja, 363-369, 2016.

Zakon o radu, N.N., br. 93/14., 127/17.

Zakon o zaštiti na radu, N.N., br. 71/14., 118/14., 154/14., 94/18., 96/18.

Zakona o obveznom zdravstvenom osiguranju, N.N., br. 80/13., 137/13. 


\section{ANALYSIS OF THE SAFETY AND HEALTH PROCESS MANAGEMENT MODEL IN THE REPUBLIC OF CROATIA}

SUMMARY: The paper presents an analysis of the model of occupational safety process management in the Republic of Croatia. The process model derives from the national legal provisions governing this area. In the first part of the paper, emphasis is placed on the theoretical settings of process management, process access, and occupational health and safety. An understanding of the theoretical assumptions is necessary in order to carry out a systematic analysis of the safety process management model. The second part of the paper presents an analysis of the safety process management model. In doing so, the key duties and responsibilities of the participants in the occupational safety management process in the Republic of Croatia are analyzed. Based on the analysis conducted, the discussion and conclusion outline opportunities for improving the process management of the occupational safety and health in the Republic of Croatia.

Key words: analysis, health and safety, model, participants, process management

Subject review

Received: 2019-10-16

Accepted: 2020-01-10 